\title{
DYNAMIC MODEL AND HYBRID DESIGN OF CURRENT FED SWITCHED INVERTER FOR DMPPT FUEL CELL SYSTEMS
}

\author{
R. Rajeswari, \\ Departmentof Electrical and Electronics Engineering, \\ College of Engineering Guindy Campus, Anna University, \\ Chennai, India. \\ rajeswari920@gmail.com
}

\begin{abstract}
A dynamic model of Polymer Electrolyte Membrane (PEM) fuel cell and hybrid design of Current-Fed Switched Inverter (CFSI) is proposed in this paper. To reduce the DC-link capacitor requirement, Current Source Inverter (CSI) is utilized instead of Voltage Source Inverter (VSI). CSI offers high reliability than VSI. The proposed converters apply to fuel cell power generation and it interfaces with single-phase grid. The high gain property of Z-Source Inverter (ZSI) and the low passive component of Switched Boost Inverter (SBI) are combined in the hybrid design of CFSI. This design achieves leading current control, maximum power generation of the fuel cell and high step-up capability of the inverter. Apart from the inverter structure, CFSI makes use of one LC filter with three switches. The proposed inverter system uses Pulse Width Modulation (PWM) based control strategy. The Distributed Maximum Power Point Tracking (DMPPT) system is used to obtain the maximum power from the source of the fuel cell.0 Using MATLAB/SIMULINK, the performance is analyzed using different topologies.
\end{abstract}

Keywords: PEM Fuel Cell, Z- Source Inverter, Current Fed Switched Inverter, Grid-Connected Hybrid System.

\section{INTRODUCTION}

The developments in the renewable energy sources and power electronic systems are used to maximize the performance of conventional power generation systems. In a renewable hybrid energy system, one or more energy sources such as wind power, solar, and fuel cell are combined. The main advantage of the hybrid system is the enhancement of reliability of the power generation system used. The main concept of the impedance source network can be applied for any power conversions such as DC-AC and AC-DC. The ZSIs can eliminate the problems in the traditional CSI and VSI. Also, the impedance network will operate in both boost and buck mode. ZSI is usually used in the many fuel cell applications to increase the efficiency and reduce cost [1-2].

By adjusting the duty cycle of the converter, it is possible to obtain maximum power for a given amount of air and hydrogen. The DMPPT is connected in series for the stability analysis of fuel cell system. There are many MPPT techniques such as artificial neural network and fuzzy logic are applied in fuel cell system applications in order to increase or decrease the reference voltage to obtain maximum power. The MPPT incremental conductance algorithm can be applied to both buck and boost power converter depending on system design [3]-[5]. The dynamic model of a controller design controller design provides an efficient optimal operation of the fuel cell. The dynamic simulation model of PEM fuel cell can be used for analysis the grid connected and standalone applications. The PEM 
fuel cell system can be easily integrated to the existing wind generations system [6]-[8].

The transformer less CSI is used in many high-power electric drives. They are analyzed in terms of efficiency, leakage current, and volume. In case of variation of DC input voltages, CSI inherits the step-up capability to obtain a gridconnected single-stage network. The leakage currents at the panel can be avoided by decoupling the fuel cell and the grid [9]-[10].

The unity power factor can be achieved by the system at the utility grid using current fed topology; the sinusoidal PWM scheme is used to control the DC link current. The CFSI converter work in both the boost and the buck modes which exhibits improved noise immunity i.e., Electromagnetic Interference (EMI). Also, the insertion of the shoot-through intervals increases the gain. Different rules are formed to eliminate the common mode source in [11-13] at switching frequency.

The dynamic model of PEM fuel cell is presented for the generation of the distributed power. The relation between the AC output and the DC inputs is established by means of the proposed design of hybrid CFSI. The incremental conductance algorithm based DMPPT is used to extract the maximum power from renewable resources. The transformer less current fed topology can be used for reduction current in the hybrid system.

\section{HYBRID SYSTEM TOPOLOGY}

In a hybrid system, the load gets power from two same sources simultaneously or separately depends on the availability of sources. The MPPT is allowed to extract the maximum power using CFSI stage from the fuel cell. A distributed MPPT based incremental conductance algorithm will be used for fuel cell system. The general structure of hybrid system topology is shown in figure 1 .

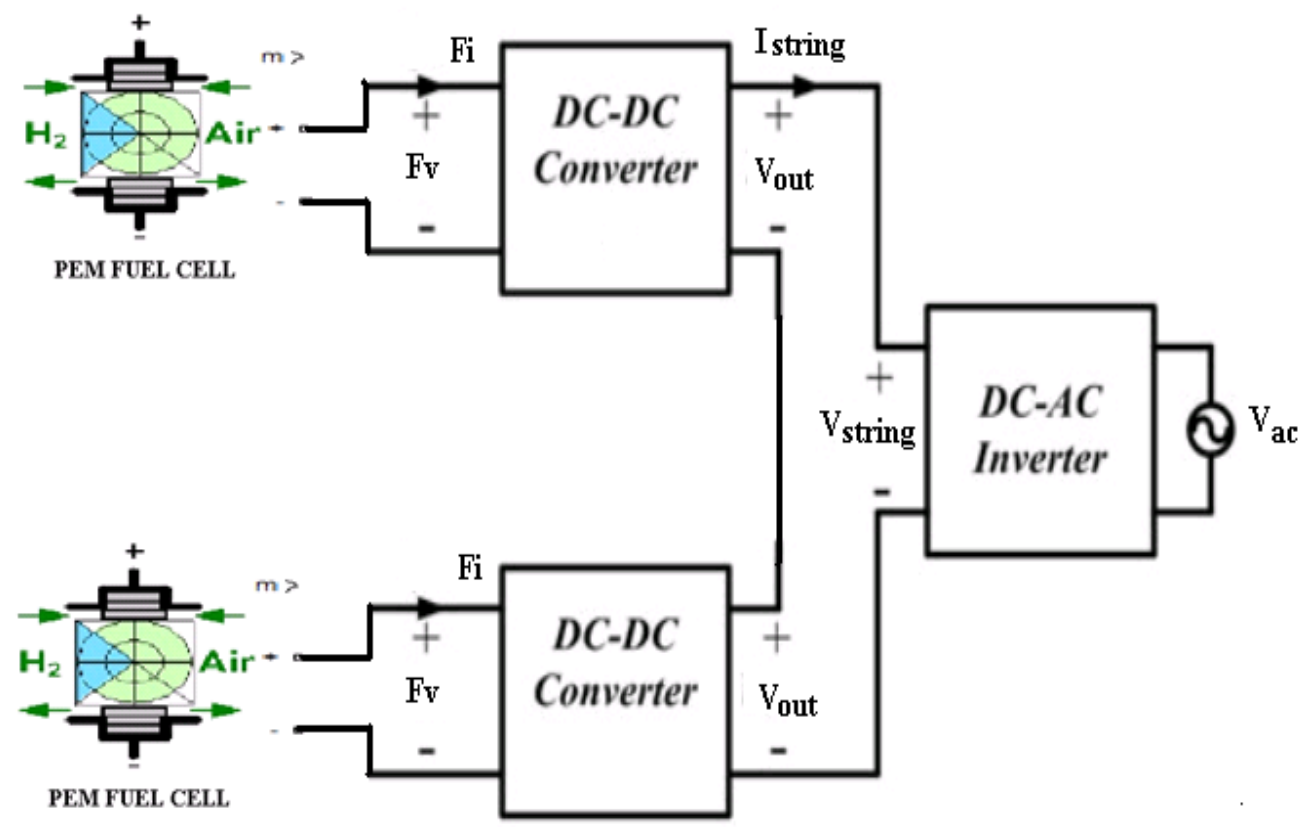

Fig. 1 Hybrid system topology 
The DC-DC converter of above-mentioned diagram indicates the CFSI. The high gain property of ZSI and the low passive component of SBI are combined in the hybrid design of CFSI. The transformer less current source inverter is used for the reduction of leakage current in this hybrid system. Figure 2 shows the circuit for topologies of the current fed switched inverter.

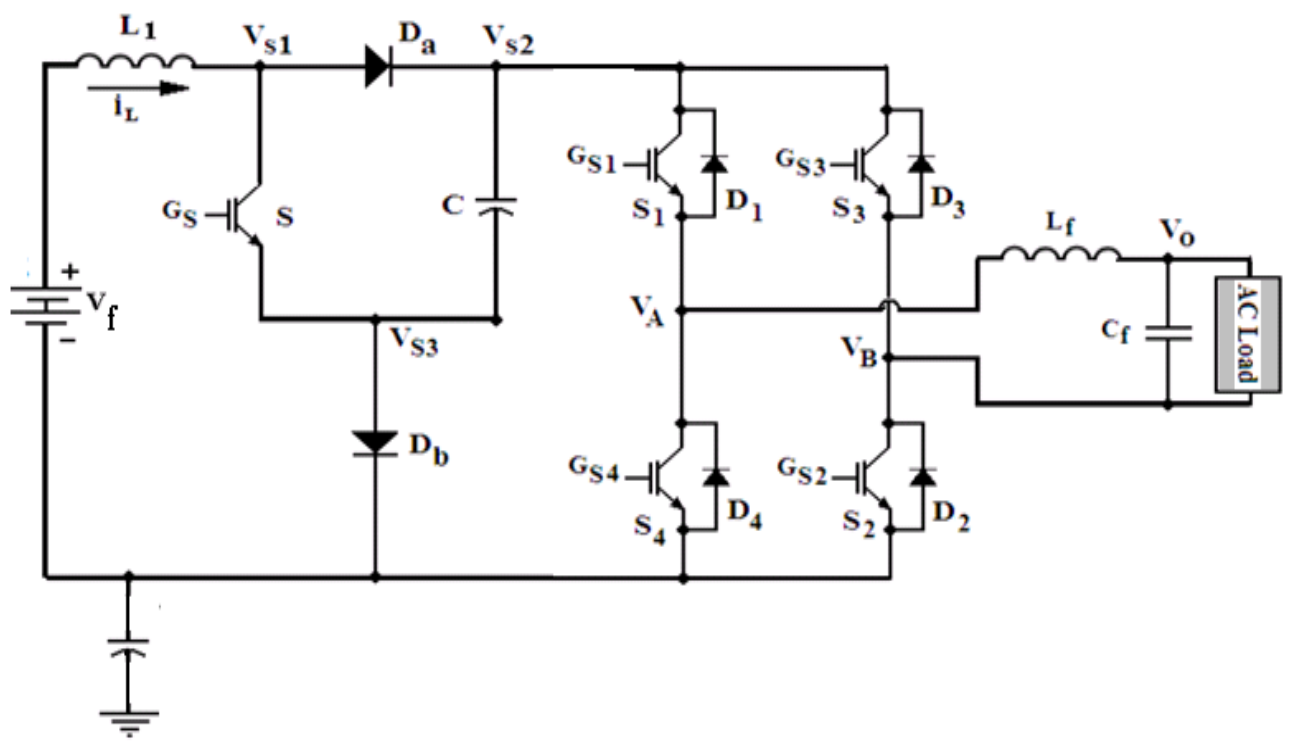

Fig. 2 Circuit for Current Fed Switched

The above circuit mentioned transformer less current source inverter based structure for fuel cell system. By proper controlling over modulation index $\mathrm{M}$ and the duty ratio $\mathrm{D}$ in inverter the boost and buck operations are achieved. Additionally, it can operate the extreme duty ratio, EMI immunity, less number of component counts, and reduces the voltage stress of switching device.

The modulation index of proposed inverter can be given as,

$$
M_{S C I}=\frac{V_{\text {out }}}{V_{f}}=\frac{1}{(1-2 D)}
$$

The inverter across the voltage can be obtained the harmonics waveform. The harmonics in the output of inverter are greatly reduced by the design of LC filter so that the load gets a clean power. The inductor ripple current depends on switching frequency and the size of the inductor. The inductance value of the filter output is given by,

$$
L_{f}=\frac{V_{d}}{4 f_{S} \mathrm{D} i}
$$

Where the frequency of the switching inverter is referred as $f_{S}$, ripple current of the inductor is referred as $\mathrm{D} i$ and DC bus voltage is referred as $V_{d}$. The capacitance value of the filter output is given by 


$$
C_{f}=\frac{\mathrm{D} i}{8 f_{S} \mathrm{D} V_{0}}
$$

where $\mathrm{DV}_{0}$ is the allowable output voltage ripple. A shoot-through operation is allowed in the inverter as its input is a switched voltage which results in a high gain and a better EMI immunity. The discontinuous problem in the input current of ZSI is eased by connecting inductor to the input terminal.

\section{FUEL CELL ENERGY GENERATION}

An energy carrier moves and delivers energy in the fuel cell. When oxygen and hydrogen in the fuel cell are combined together, it can produce more water, heat, and electricity. Various types of fuel cells are used for real-time applications. In many applications like power trains, mobiles, polymer electrolyte membrane (PEM) fuel cells are widely used. A dynamic model is proposed to simulate a PEMFC which accounts for the effects of different operating conditions.

Total Cell Reaction: $2 \mathrm{H}_{2}+\mathrm{O}_{2}{ }^{\circledR} 2 \mathrm{H}_{2} \mathrm{O}+$ electricity + heat

$$
\text { Cathode Reaction: } \mathrm{O}_{2}+4 \mathrm{H}^{+}+e^{-} \text {( } 2 \mathrm{H}_{2} \mathrm{O}
$$

$$
\text { Anode Reaction: } 2 \mathrm{H}_{2}{ }^{\circledR} 4 H^{+}+4 e^{-}
$$

The basic working of fuel cells involves diffusion of charges between the electrodes. The cell voltage is given Eqn. 7 .

$$
V_{\text {cell }}=E_{\text {thermo }}-V_{\text {act }}-V_{\text {ohmic }}-V_{\text {conc }}
$$

where thermo, act, ohmic and conc are thermal losses, activation losses, ohmic losses and concentric losses respectively.

$$
\begin{gathered}
E_{\text {thermo }}=1.229-8.5^{\prime} 10^{-4}(T-298.15)+4.318^{\prime} 10^{-4} T \underset{\varepsilon}{\stackrel{e}{e}}\left(P_{H_{2}}\right)+\frac{1}{2} \ln \left(P_{O_{2}}\right) \text { ùj } \\
V_{\text {act }}=K_{1}+K_{2} T+K_{3} T \ln \left(C_{2}\right)+K_{4} T \ln (I) \\
V_{\text {ohmic }}=I\left(R_{\text {membrane }}\right) \\
V_{\text {conc }}=K_{6} e^{\left(K_{7} I\right)}
\end{gathered}
$$

The anode and cathode flow equations depend upon the membrane content of water. Figure 3 shows the Simulink model of the fuel cell. 


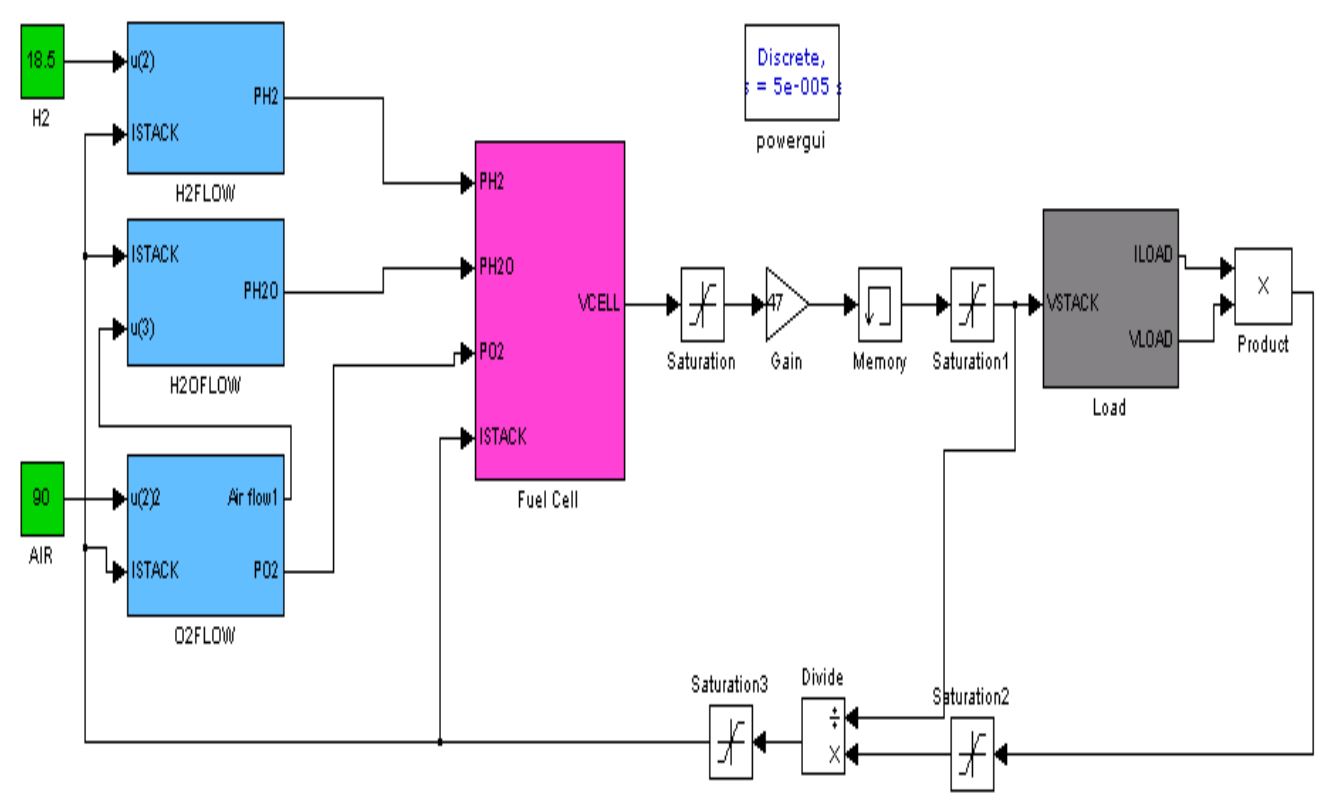

Fig. 3 PEM fuel cell Simulink Model

Anode flow model equations,

$$
\frac{V_{a}}{R T} \frac{d P_{H_{2}}}{d t}=\stackrel{\mathrm{g}}{M} H_{2, \text { in }}-\stackrel{\mathrm{g}}{M} H_{2, \text { out }}-\frac{1}{2 F}
$$

Cathode flow model equations,

$$
\frac{V_{c}}{R T} \frac{d P_{o_{2}}}{d t}=\stackrel{\mathrm{g}}{M_{o_{2, i n}}}-\stackrel{\mathrm{g}}{M}_{o_{2, \text { out }}}-\frac{1}{4 F}
$$

Total flow model equations,

$$
\frac{V_{c}}{R T} \frac{d P_{H_{2} O}}{d t}=\stackrel{\mathrm{g}}{M} H_{2} O, \text { in }^{-} \stackrel{\stackrel{\mathrm{g}}{M}}{H_{2} O, o u t}+\frac{1}{2 F}
$$

The product between the number of cells and the voltage is said to be as the voltage of the stack and is given as,

$$
V_{\text {stack }}=V_{\text {cell }}{ }^{\prime} N
$$

Here, the $V_{\text {cell }}$ acts as the functions of cell temperature, the density of current, membrane hydration, and pressure of the reactants. When all the cells 
are connected in series, the product of a number of cells $(\mathrm{N})$ and cell potential gives the stack output.

\section{TRACKING OF MAXIMUM POWER POINT}

The MPPT helps in obtaining the maximum power output by providing automatic adjustment of loads in the fuel cell system. The maximum amount of power is achieved when the higher or lower output current produced by the panel are in complement with the varying air, stack current, voltage, and hydrogen at MPP. The power curve of MPPT is shown in figure 4.

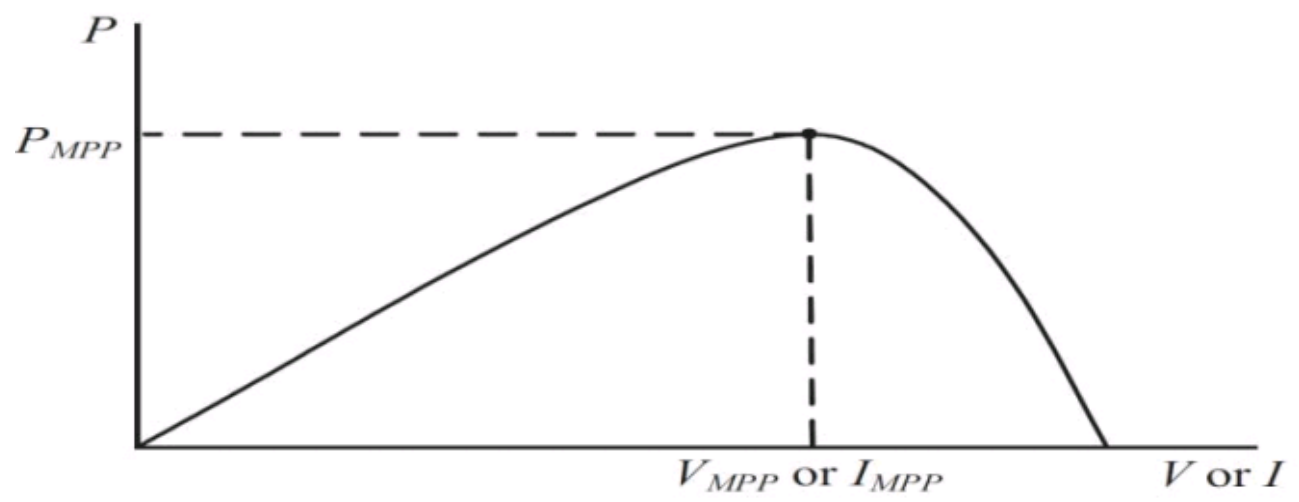

Fig. 4 MPPT Power curve

As explained below, a maximum amount of power is drawn from the fuel cells to keep the current curve voltage at the peak point. For testing the distributed efficiency as well as the centralized MPPT with two types of topologies; stack current and hydrogen are used in the MPPT system. The Simulink block of MPPT is shown in figure 5 .

\section{SIMULATION RESULTS}

The proposed system is made-up of a single phase inverter with filters along with the DC-DC power converters. The utility grid gets the high-quality AC power from the single-phase inverters which convert DC power into AC power. The voltages are regulated by using LC filter. To extract the maximum power from the fuel cell systems, the current fed switched inverter performs MPPT. The reduction of leakage current can be achieved by using transformer less structure. MATLAB/SIMULINK tool is used to verify the overall proposed topology. The Simulink model of the proposed scheme with filter and without the filter and their performance analyses are shown in Figure 6 to Figure 13. 
Int. J.Adv.Sig.Img.Sci, Vol. 1, No. 1, 2015

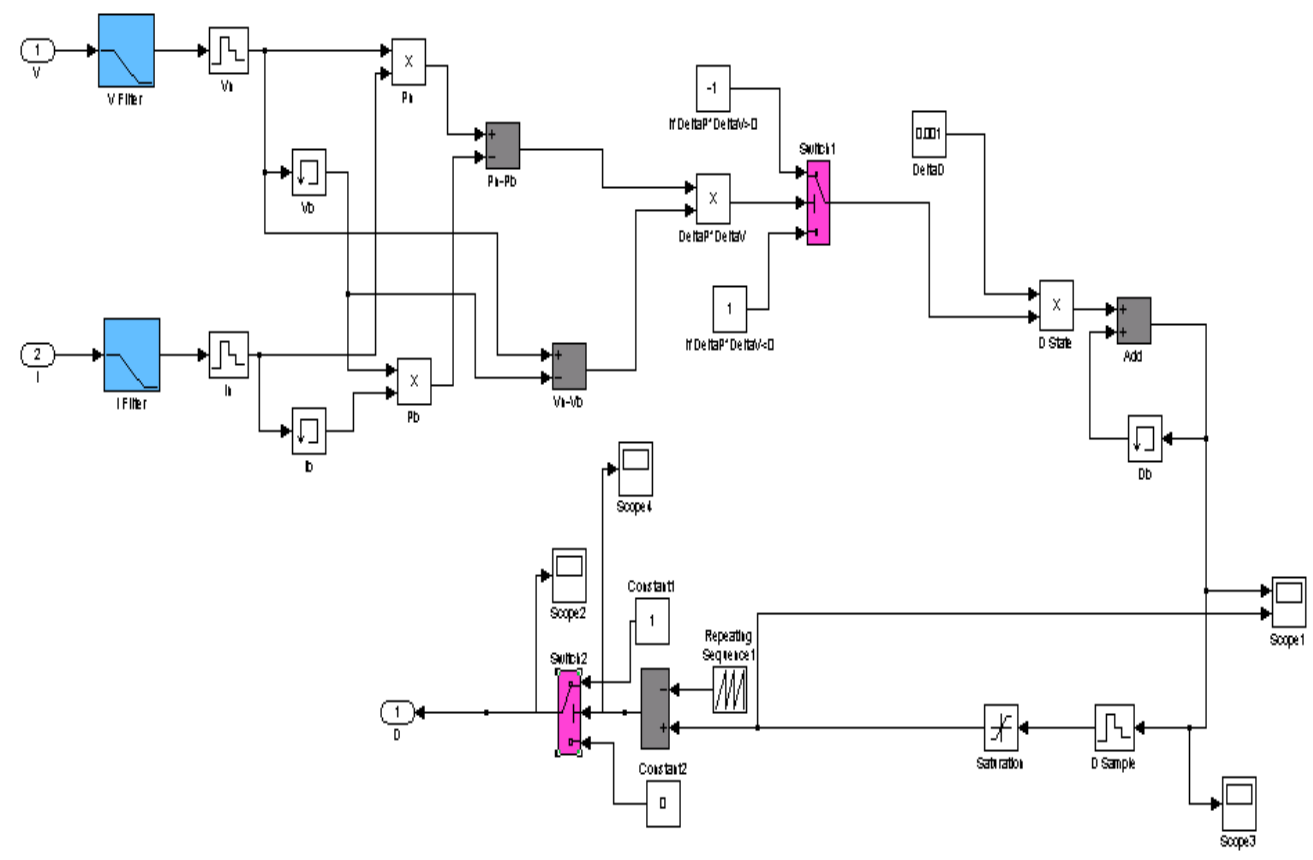

Fig. 5 Incremental and Conductance of MPPT algorithm

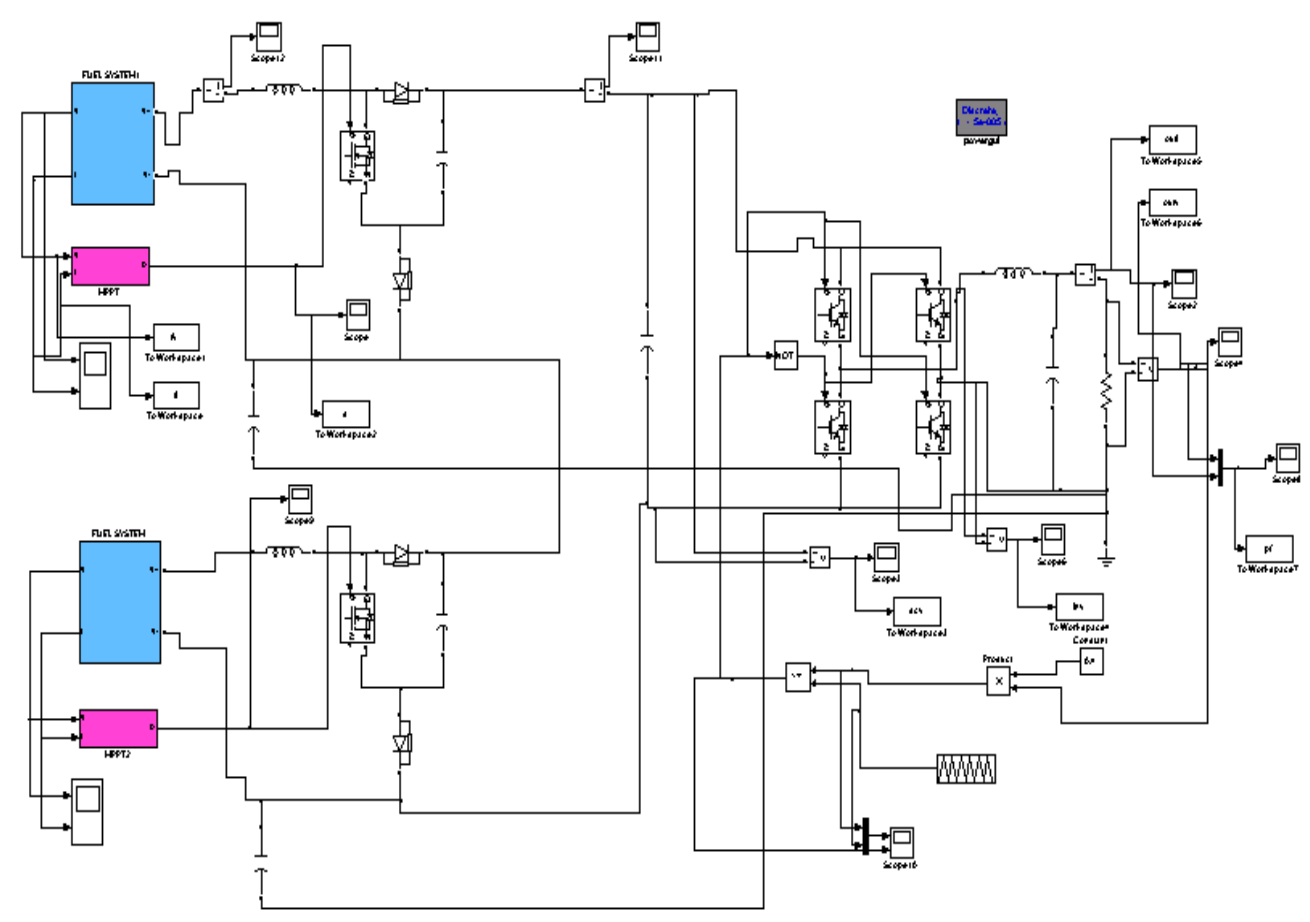

Fig. 6 Simulink model of proposed topology with filter 

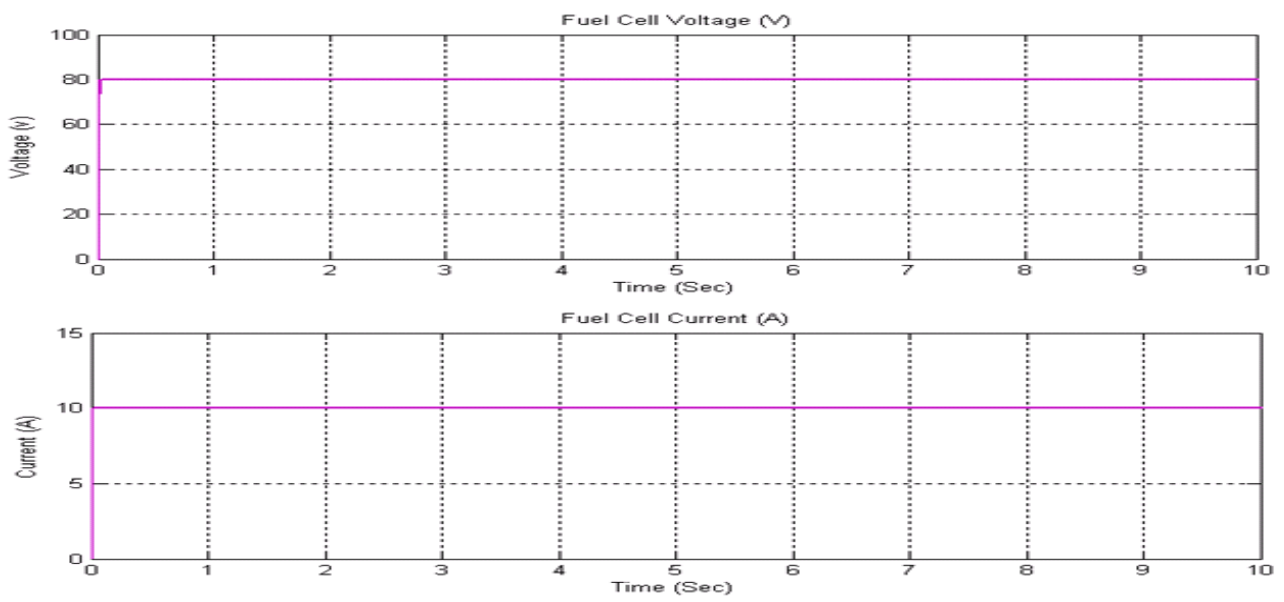

Fig. 7 Fuel cell voltage and current waveform

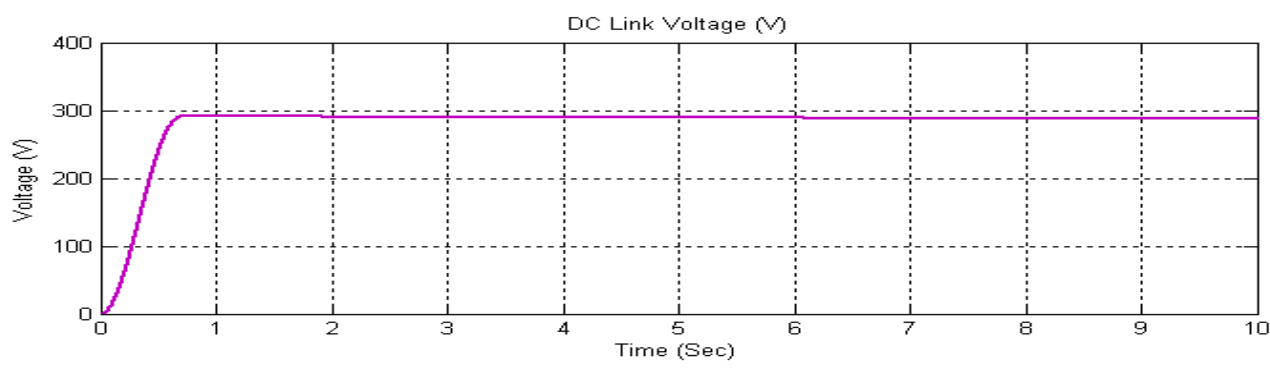

Fig. 8 Voltage waveform of DC Link

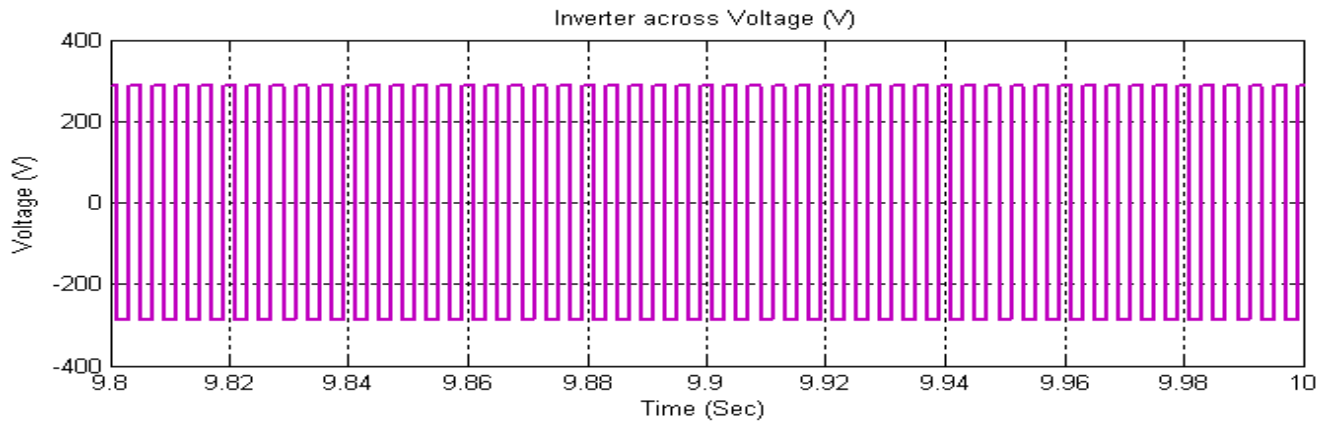

Fig. 9 Inverter across voltage waveform 

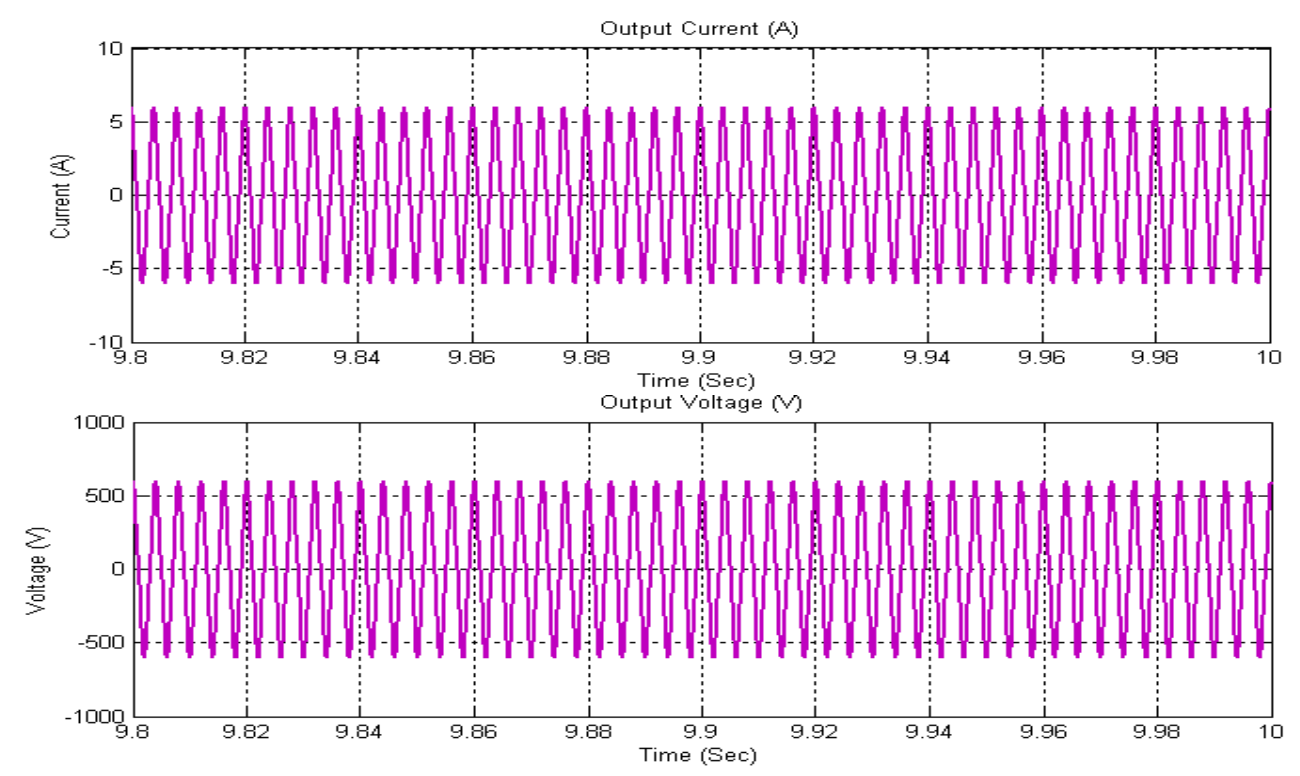

Fig. 10 Current Waveform and its Output Voltages using filter
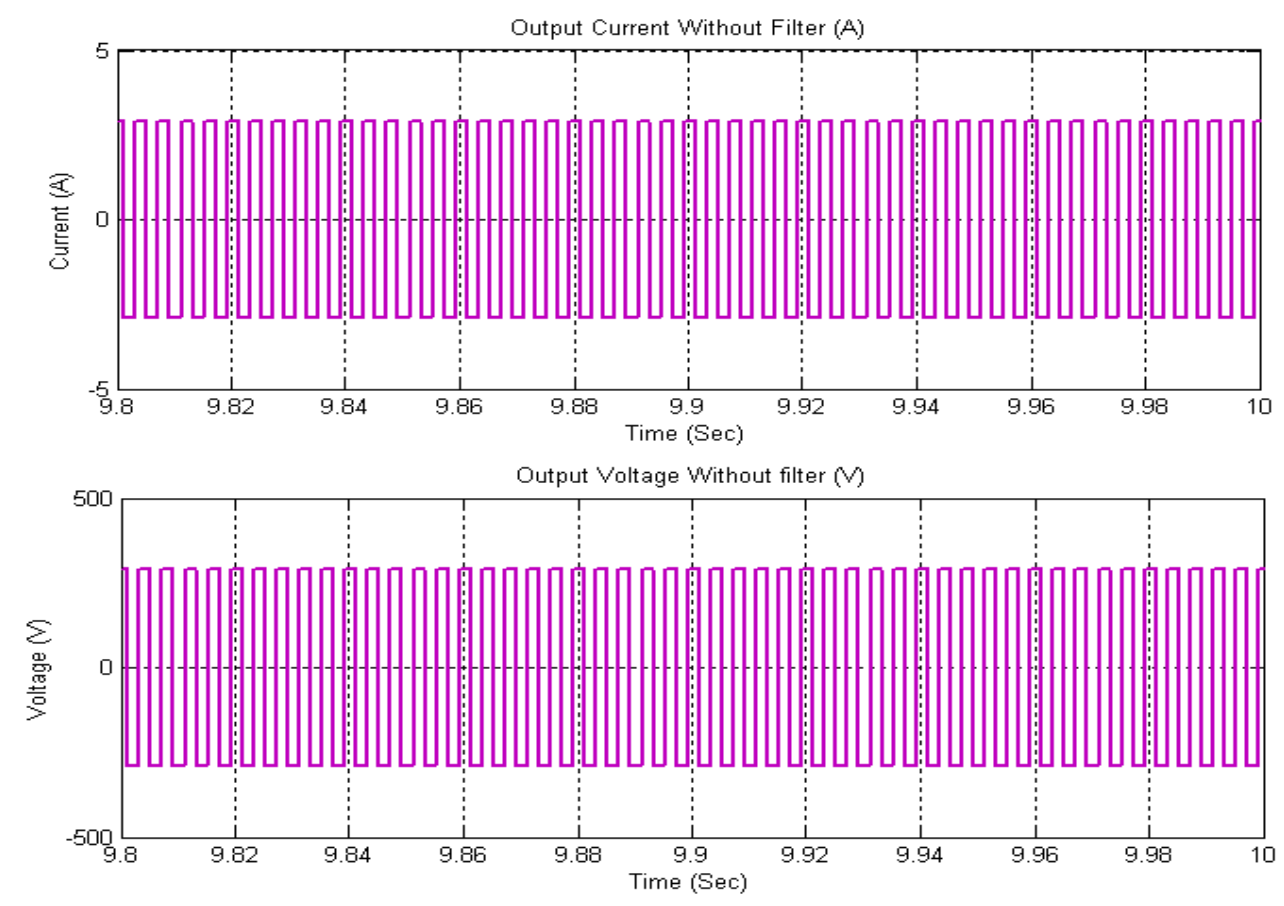

Fig. 11 Current Waveform and its Output Voltage without using filter 


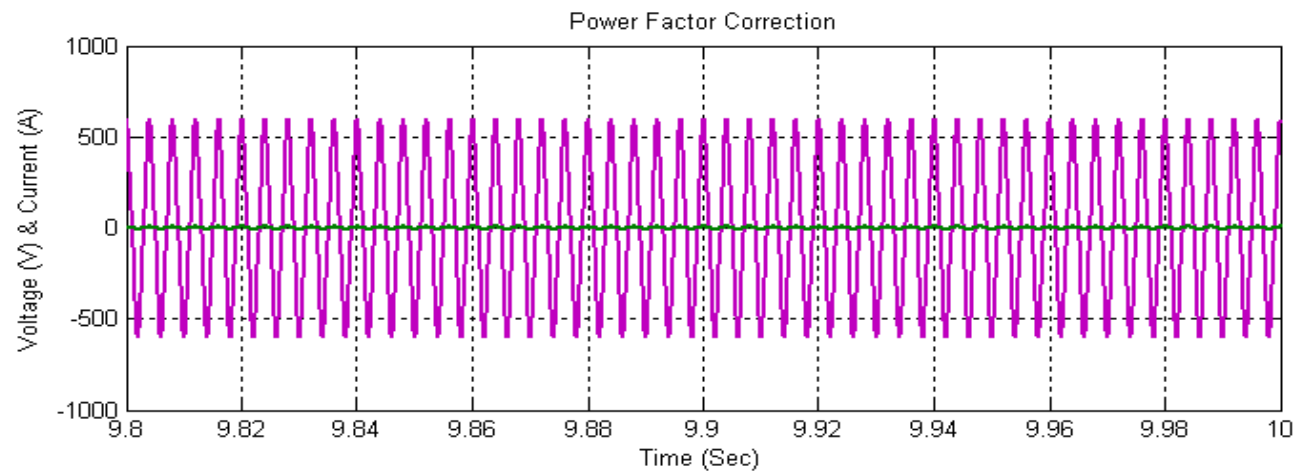

Fig. 12 Power Factor Correction (PFC)

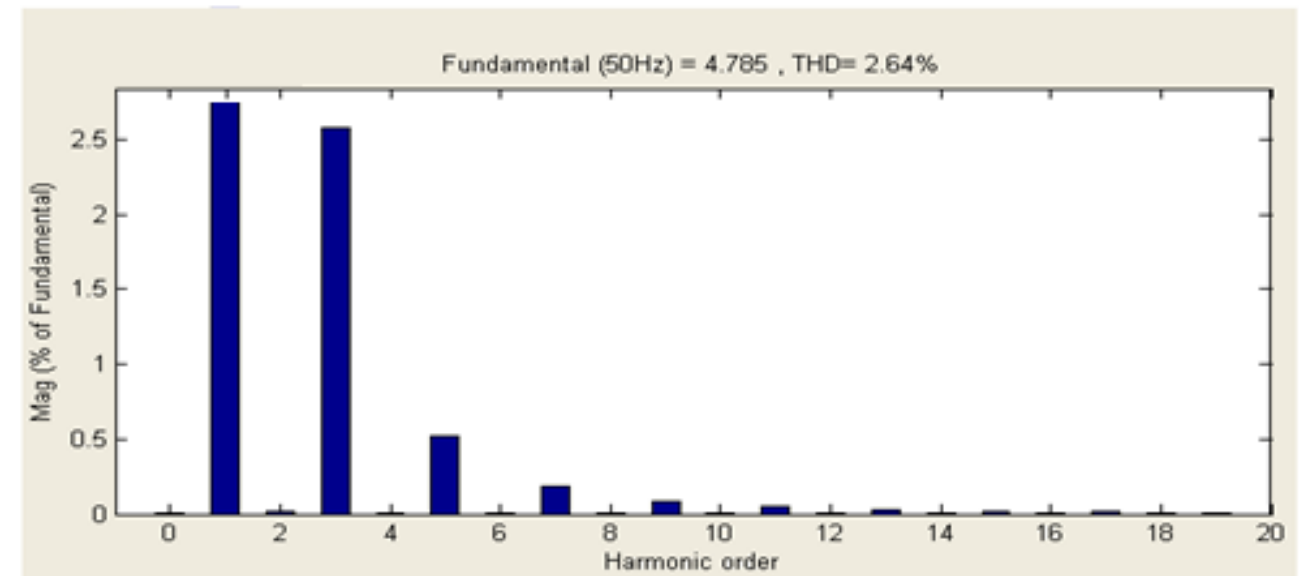

Fig. 13 Total Harmonic Distortion at output side current

Total harmonic distortion is computed by Fast Fourier Transform analysis tool which is provided in Simulink model in the form of powergui. The analysis shows that the harmonic content in the output current is a small value and it is more than $2.64 \%$ in Figure 13. Table 1 shows the various simulation parameter values.

TABLE 1 Simulation Setup

\begin{tabular}{|c|c|}
\hline Parameters & Values \\
\hline Fuel Cell Voltage (Vin) & $80 \mathrm{~V}$ \\
\hline Fuel Cell Current (Cin) & $10 \mathrm{~A}$ \\
\hline $\begin{array}{c}\text { Converter Switching } \\
\text { Frequency }\left(f_{S w}\right)\end{array}$ & $50 \mathrm{HZ}$ \\
\hline DC voltage $\left(V_{d c}\right)$ & $280 \mathrm{~V}$ \\
\hline Filter of L $\left(L_{f}\right)$ & $25 \mathrm{e}-4 \mathrm{H}$ \\
\hline Filter of $\left(C_{f}\right)$ & $55 \mathrm{e}-6 \mathrm{~F}$ \\
\hline
\end{tabular}




\section{CONCLUSION}

In this paper, a hybrid design of current fed switched inverter for DMPPT fuel cell systems is proposed. The distributed MPPT is used to extract the maximum amount of power from the fuel cell system. Also, in order to achieve to extract the lagging current from lagging limits, cost, and improvement of efficiency. It exhibits an improved EMI noise immunity and can work in either boost mode or buck mode. The fuel cell's dynamic performance of the system and the PWM switching scheme on modulation index has also been presented. The transformer less current source inverter used for reduction of leakage current. The performance of fuel power generation, converter operation and controller performance are analyzed and verified by using simulation in MATLAB. Also, the power factor correction and Total Harmonic Distortion can be verified with simulation results.

\section{REFERENCES}

[1]. M. Hanif, M. Basu, and K. Gaughan, "Understanding the operation of a Zsource inverter for photovoltaic application with a design example", IET Power Electron, Vol. 4, No. 3, 2011, pp. 278-287.

[2]. $\quad$ F.Z. Peng, "Z-source inverter", IEEE Transactions on industry applications, Vol. 39, No. 2, 2003, pp. 504-510.

[3]. M. Abdulkadir, A.S. Samosir, A.H.M. Yatim, and S.T. Yusuf, "A new approach of modeling, simulation of MPPT for photovoltaic system in Simulink model", ARPN Journal of Engineering and Applied Sciences, Vol. 8, No. 7, 2013, pp. 488-494.

[4]. C.W. Chen, K.H. Chen, and Y.M. Chen, "Modeling and controller design of an autonomous PV module for DMPPT PV systems", IEEE Transactions on power electronics, Vol. 29, No. 9, 2014, pp. 4723-4732.

[5]. A. Soetedjo, "Modeling of maximum power point tracking controller for solar power system", Indonesian Journal of Electrical Engineering and Computer Science, Vol. 10, No. 3, 2012, pp. 419-430.

[6]. A.B. Cultura, and Z.M. Salameh, "Dynamic analysis of a standalone operation of PEM fuel cell system", Journal of Power and Energy Engineering, Vol. 2, No. 1, 2014, pp. 1-8.

[7]. Z. Ural, M.T. Gencoglu, and B. Gumus, "Dynamic simulation of a PEM fuel cell system", In Proceedings of $2^{\text {nd }}$ International Hydrogen Energy Congress and Exhibition, 2007, pp. 1-12.

[8]. G. Dotelli, R. Ferrero, P.G. Stampino, S. Latorrata, and S. Toscani, "Diagnosis of PEM fuel cell drying and flooding based on power converter ripple", IEEE Transactions on Instrumentation and Measurement, Vol. 63, No. 10, 2014, pp. 2341-2348.

[9]. W.T. Franke, N. Oestreich, and F.W. Fuchs, "Comparison of transformerless converter topologies for photovoltaic application concerning efficiency and mechanical volume", IEEE International Symposium on Industrial Electronics, 2010, pp. 724-729.

[10]. E. Lorenzani, F. Immovilli, C. Bianchini, and A. Bellini, "Performance analysis of a modified Current Source Inverter for photovoltaic microinverter applications", IEEE 39th Annual Conference of the Industrial Electronics Society, 2013, pp. 1809-1814.

[11]. D. Amorndechaphon, S. Premrudeepreechacharn, and K. Higuchi, "Modified grid-connected current source inverter for multi-string PV system", IEEE PES in Innovative Smart Grid Technologies, 2011, pp. 1-8. 
[12]. S.S. Nag, and S. Mishra, "Current-fed switched inverter", IEEE Transactions on Industrial Electronics, Vol. 61, No. 9, 2014, pp. 46804690.

[13]. H. Xiao, and S. Xie, "Leakage current analytical model and application in single-phase transformerless photovoltaic grid-connected inverter", IEEE Transactions on Electromagnetic Compatibility, Vol. 52, No. 4, 2010, pp. 902-913. 